\title{
Dynamics of gas levels inside packages containing minimally processed Pera orange
}

\author{
Dinâmica dos níveis gasosos dentro de embalagens contendo laranja Pera minimamente processada
}

\author{
Maria Cecília de Arruda PALHARINI ${ }^{1 \star}$, Angelo Pedro JACOMINO², Ana Luíza PINHEIRO², \\ Marcos José TREVISAN² ${ }^{2}$ Claire Isabel Grígoli de Luca SARANTÓPOULOS 3
}

\begin{abstract}
The purpose of this study was to evaluate the changes in concentrations of $\mathrm{O}_{2}$ and $\mathrm{CO}_{2}$ inside packages of minimally processed Pera orange. Previously selected oranges that were washed, sanitized, and chilled were peeled using hydrothermal treatment (immersion of fruits in water at $50{ }^{\circ} \mathrm{C}$ for 8 minutes). The peeled oranges were then packed in five different plastic packages under passive and active modified atmosphere $\left(5 \% \mathrm{O}_{2}+10 \% \mathrm{CO}_{2}+85 \% \mathrm{~N}_{2}\right)$. The fruits were stored at $6{ }^{\circ} \mathrm{C}$ and $12{ }^{\circ} \mathrm{C}$. The package headspace gas composition was evaluated for twelve days at $6{ }^{\circ} \mathrm{C}$ and nine days at $12{ }^{\circ} \mathrm{C}$. The polypropylene film $(32 \mu \mathrm{m})$ promoted modified atmosphere similar to that initially injected (5\% $\mathrm{O}_{2}+10 \% \mathrm{CO}_{2}+85 \% \mathrm{~N}_{2}$ ) at $6{ }^{\circ} \mathrm{C}$ and $12{ }^{\circ} \mathrm{C}$. With regard to the atmosphere modification system, the injection of a gas mixture anticipated achieving an equilibrium atmosphere inside the packages at $12{ }^{\circ} \mathrm{C}$. At $6^{\circ} \mathrm{C}$, the gas composition inside the packages was kept close to that of the injection, but the equilibrium was not verified.

Keywords: Citrus sinensis; modified atmosphere package; refrigeration; minimal processing.
\end{abstract}

\section{Resumo}

O objetivo deste trabalho foi avaliar as mudanças nas concentrações de $\mathrm{O}_{2} \mathrm{e} \mathrm{CO}_{2}$ do interior de embalagens contendo laranja Pera minimamente processada. Laranjas previamente selecionadas, lavadas, sanitizadas e resfriadas foram descascadas por meio de tratamento hidrotérmico (imersão dos frutos em água a $50{ }^{\circ} \mathrm{C}$ por 8 minutos). Laranjas descascadas foram acondicionadas em cinco materiais de embalagem sob atmosfera modificada passiva e atmosfera modificada ativa $\left(5 \% \mathrm{O}_{2}+10 \% \mathrm{CO}_{2}+85 \% \mathrm{~N}_{2}\right)$. O armazenamento dos frutos foi realizado a $6{ }^{\circ} \mathrm{C}$ e $12^{\circ} \mathrm{C}$. A composição gasosa no interior das embalagens foi avaliada durante doze dias a $6{ }^{\circ} \mathrm{C}$ e durante 9 dias a $12^{\circ} \mathrm{C}$. O filme de polipropileno $(32 \mu \mathrm{m})$ propiciou atmosfera modificada semelhante à injetada inicialmente $\left(5 \% \mathrm{O}_{2}+10 \% \mathrm{CO}_{2}+85 \% \mathrm{~N}_{2}\right)$ a $6{ }^{\circ} \mathrm{C}$ e $12{ }^{\circ} \mathrm{C}$. Em relação ao sistema de modificação da atmosfera, a injeção de mistura gasosa antecipou a atmosfera de equilíbrio, dentro das embalagens a $12^{\circ} \mathrm{C}$. A $6^{\circ} \mathrm{C}$, a composição gasosa dentro das embalagens foi mantida próxima dos níveis de injeção, mas o equilíbrio não foi verificado.

Palavras-chave: Citrus sinensis; embalagem com atmosfera modificada; refrigeração; processamento mínimo.

\section{Introduction}

One of the main problems with minimally processed products is their short life-span. Tissue injuries caused by cutting increase respiratory activity and ethylene production, especially during the first hours after they have been cut, peeled, or shredded (ARTÉS; GÓMEZ; ARTÉS-HERNÁNDEZ, 2007).

The presence of damaged cells and the loss of cellular components during processing operations provide optimum conditions for the development of microrganisms. The type and species, as well as the microbial levels in the minimally processed products vary according to the fruit or vegetable and growing and hygienic conditions during handling and processing, storage temperature, and other factors (ARTÉS; GÓMEZ; ARTÉS-HERNÁNDEZ, 2007).

The removal of the natural protection given by the albedo and the flavedo in oranges results in physiological changes, such as dehydration, senescence, and metabolic changes. As a consequence of the loss of vesicular juice and the absence of skin protection, fruits are more susceptible to microbiological attack, (PRETEL et al., 1998). Therefore, the use of modified atmosphere packaging is interesting since it has a direct impact on the physiological and biochemical processes of minimally processed vegetables and on the reduction of microbial proliferation, thus extending the shelf-life of fruits.

Modified atmosphere in a plastic package can be achieved in a passive or in an actively way. The passive atmosphere results from the product respiration, while the active modified atmosphere is achieved by flushing gases at the moment of packing (KADER, 1986). The atmosphere is maintained by packaging materials having specific $\mathrm{O}_{2}$ and $\mathrm{CO}_{2}$ transmission rates, which promote adequate gas concentrations for a specific product at a given temperature (AHVENAINEN,

\footnotetext{
Received 24/5/2010

Accepted 3/7/2012 (004859)

${ }^{1}$ Agência Paulista de Tecnologia dos Agronegócios - APTA, Pólo Regional de Desenvolvimento Tecnológico dos Agronegócios do Centro Oeste Paulista, Sede Bauru,

Av. Rodrigues Alves, 4040, CEP 17030-000,Bauru, SP, Brasil, e-mail: mcarruda@apta.sp.gov.br

Departamento de Produção Vegetal, Escola Superior de Agricultura “Luiz de Queiroz" - ESALQ, Universidade de São Paulo - USP, CP 09, CEP 13418-900,

Piracicaba, SP, Brasil

${ }^{3}$ Instituto de Tecnologia de Alimentos, Centro de Tecnologia de Embalagens, CP 139, CEP 13070-178, Campinas, SP, Brasil

${ }^{*}$ Corresponding author
} 
1996; BARMORE, 1987). However, fluctuations in storage temperature affect gas contents inside packages since the increase in temperature has a differentiated impact on the vegetable respiratory activity and on the gas permeability of the packaging components (SARANTÓPOULOS et al., 1996).

The atmospheres ranging from $3-8 \% \mathrm{O}_{2}$ and $5-15 \% \mathrm{CO}_{2}$ show good potential to keep the quality of minimally processed produce although there is a specific atmosphere that maximizes shelf-life for each vegetable (CANTWELL, 1992).

The objective of this study was to evaluate the changes in concentrations of $\mathrm{O}_{2}$ and $\mathrm{CO}_{2}$ inside packages of minimally processed 'Pera' orange.

\section{Material and methods}

Pera oranges obtained from commercial orchards in Engenheiro Coelho-SP were washed with neutral detergent, sanitized with chlorinated water ( $200 \mathrm{mg}$ of active chlorine $\mathrm{L}^{-1}$ ) for 10 minutes and cooled to $6{ }^{\circ} \mathrm{C}$ for 12 hours. The fruits were then submitted to hydrothermal treatment and peeled.

The hydrothermal treatment consisted of immersing the oranges in heated water $\left(50^{\circ} \mathrm{C}\right)$ for eight minutes (ARRUDA et al., 2008). Then, the fruits were immediately peeled by first opening a gap in the peduncular region with a knife, and then the flavedo and albedo were manually removed.

Peeled oranges were packed (packaging is described in Table 1) under two modified atmosphere systems (passive and active: $5 \% \mathrm{O}_{2}+10 \% \mathrm{CO}_{2}+85 \% \mathrm{~N}_{2}$ ). The composition of the gas mixtures injected was chosen according to values recommended by Cantwell (1992) for the maintenance of quality of minimally processed products $\left(3-8 \% \mathrm{O}_{2}+5-15 \% \mathrm{CO}_{2}\right)$. Oranges packed in expanded polystyrene trays covered with PVC stretch film and stored at $6{ }^{\circ} \mathrm{C}$ and $12{ }^{\circ} \mathrm{C}$ were taken as control.

The packaging materials studied were previously selected according to their gas permeability and fruit respiratory activity at $6{ }^{\circ} \mathrm{C}$. This selection was based on a mathematical model in which the $\mathrm{O}_{2}$ mass consumed by respiration must equal the oxygen permeability of the package. As for the carbon dioxide, its production by fruit respiration must equal the package $\mathrm{CO}_{2}$ permeability.

According to the adopted mathematical model, the necessary permeability rates for respiration gases to promote the establishment of a optimized equilibrium atmosphere of $5 \% \mathrm{O}_{2}$ and $10 \% \mathrm{CO}_{2}$ inside the package containing minimally processed oranges stored at $6^{\circ} \mathrm{C}$ would be $3,271 \mathrm{~mL} \mathrm{O}(\mathrm{STP}) \cdot \mathrm{m}^{-2} \cdot \mathrm{dia}^{-1}$, $6,261 \mathrm{~mL} \mathrm{CO}{ }_{2}(\mathrm{STP}) \cdot \mathrm{m}^{-2} \cdot \mathrm{dia}^{-1}$ at $23^{\circ} \mathrm{C}$, and a gradient of partial pressure of the permeating gas of $1 \mathrm{~atm}$.
Four films were chosen according to theirs gas permeability rates. Two of the films chosen showed $\mathrm{TPO}_{2}$ values close to the desired equilibrium atmosphere of $5 \% \mathrm{O}_{2}+10 \% \mathrm{CO}_{2}$. The third film showed values slightly below this atmosphere, and the fourth film showed figures above these values (PVC, in this last case, which was used as control).

The effective permeation area of polypropylene and Cryovac PD-900 packages containing about $500 \mathrm{~g}$ of fruit was $900 \mathrm{~cm}^{2}$. Expanded polystyrene trays wrapped with PVC stretch film containing about $300 \mathrm{~g}$ of fruit showed an effective permeation area of $300 \mathrm{~cm}^{2}$.

The experimental design was completely randomized with six replications. Each replicate was represented by one type of packaging.

Headspace gas composition monitoring was carried out during 12 days at $6{ }^{\circ} \mathrm{C}$ and nine days at $12{ }^{\circ} \mathrm{C}$. Headspace gas samples (about $2 \mathrm{~mL}$ ) were collected using PTFE silicone septa fixed on the package surface. A Check Mate gas analyzer (PBIDansensor) was used to measure $\mathrm{O}_{2}$, and $\mathrm{CO}_{2}$ concentrations were expressed in $\%(\mathrm{v} / \mathrm{v})$ of gas.

\section{Results and discussion}

The gas composition inside the packages containing minimally processed oranges varied according to packaging material, modified atmosphere system, and storage temperature (Figures 1 and 2).

The PVC film caused minor modifications in the atmosphere, which was expected due to its high permeability rates to $\mathrm{O}_{2}$ and $\mathrm{CO}_{2}$ In this package, $\mathrm{O}_{2}$ was reduced up to $17.70 \%$, while there was a $\mathrm{CO}_{2}$ accumulation up to $2.03 \%$. As for the other packaging materials under passive modified atmosphere, there was an increase in $\mathrm{CO}_{2}$ levels and a decrease in $\mathrm{O}_{2}$ levels throughout the storage period, followed or not by gas stabilization levels.

$\mathrm{CO}_{2}$ accumulation inside the PP $44 \mu \mathrm{m}$ film was $30 \%$ higher than the accumulation observed for the PP $32 \mu \mathrm{m}$ package, reaching levels of about $12 \%$, either at $6^{\circ} \mathrm{C}$ or at $12{ }^{\circ} \mathrm{C}$. High $\mathrm{CO}_{2}$ accumulation is desirable since high $\mathrm{CO}_{2}$ levels provide some benefits, such as enzymatic activity reduction and the prevention of fungi and bacteria development (PANTÁSTICO, 1975; ROBERTSON, 2006). Pretel et al. (1998) observed a reduction in the growth of total mesophyll (including psychrotrophic) in oranges under an atmosphere rich in $\mathrm{CO}_{2}$. In atmospheres containing up to $25 \% \mathrm{CO}_{2}$, an increase of less than $1 \log$ cycle was observed, while in atmospheres containing up to $10 \% \mathrm{CO}_{2}$, the number of microorganisms increased more than $2 \log$ cycles. The same was observed by Arruda et al. (2004), who reported

Table 1. Gas transmission (TR $)^{1}$ to gases for the packaging materials studied.

\begin{tabular}{lccr}
\hline \multicolumn{1}{c}{ Packaging material } & Thickness $(\mu \mathrm{m})$ & $\mathrm{O}_{2} \mathrm{TR} \mathrm{mL}(\mathrm{STP}) / \mathrm{m}^{2}$.day & $\mathrm{CO}_{2} \mathrm{TR} \mathrm{mL}(\mathrm{STP}) / \mathrm{m}^{2}$.day \\
\hline Polypropylene film (PP) & 32 & 3,065 & 6,189 \\
Polypropylene film (PP) & 44 & 1,662 & 4,153 \\
Polyolefin film Cryovac PD-900 - (PO) & 58 & 3,433 & 15,946 \\
PVC stretch film & 20 & 10,446 & 69,843 \\
\hline
\end{tabular}

${ }^{1}$ Dry determination at $23^{\circ} \mathrm{C}$, partial pressure of gas of $1 \mathrm{~atm}$. 

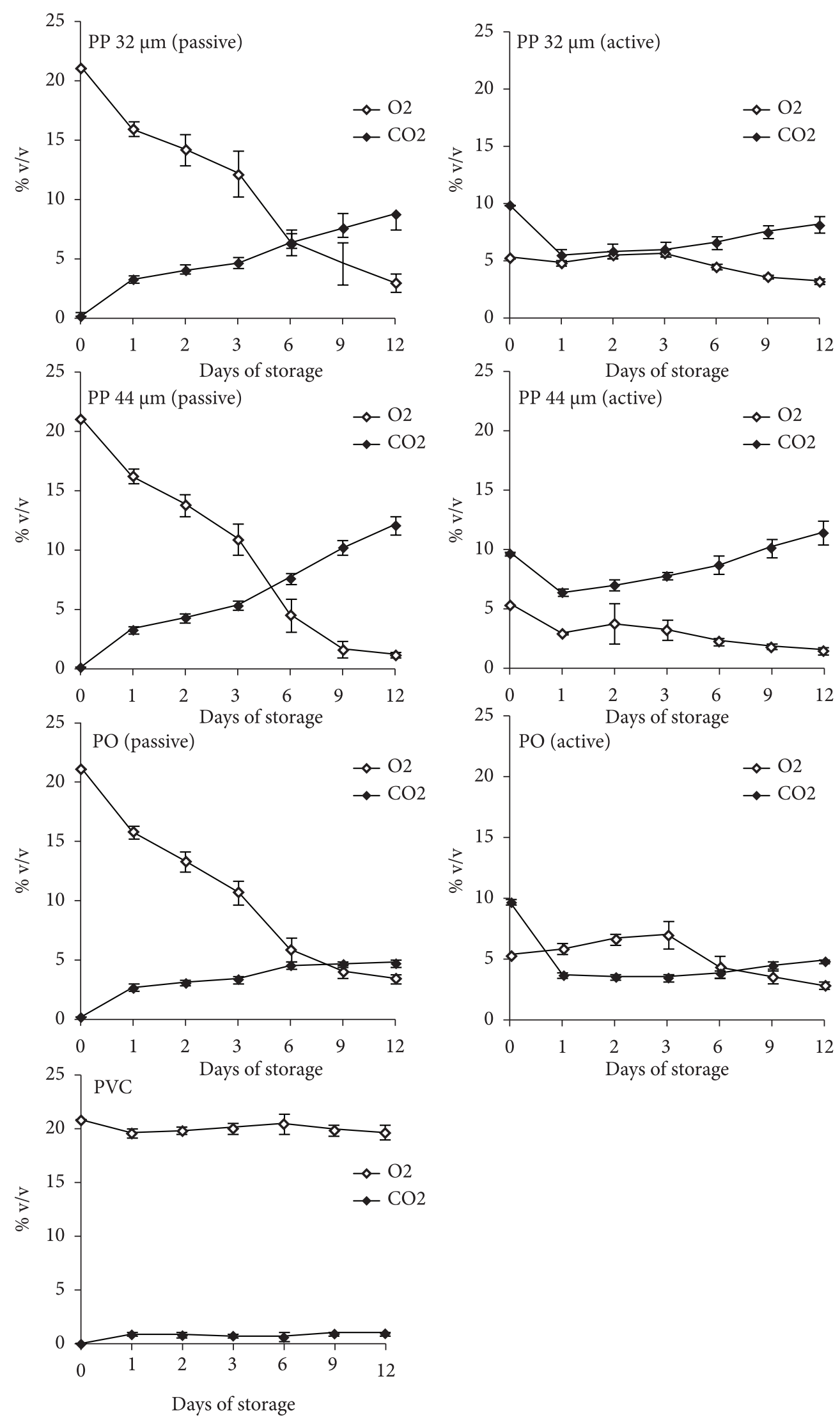

Figure 1. Gas composition ( $\% \mathrm{v} / \mathrm{v})$ in packaging under passive or active atmosphere $\left(5 \% \mathrm{O}_{2}+10 \% \mathrm{CO}_{2}+85 \% \mathrm{~N}_{2}\right)$ containing minimally processed oranges stored at $6^{\circ} \mathrm{C}$. Bars represent the standard deviation from the mean $(\mathrm{n}=6)$. PP: polypropylene film; PO: polyolefin film Cryovac PD-900; PVC: polystyrene trays covered with PVC stretch film. 

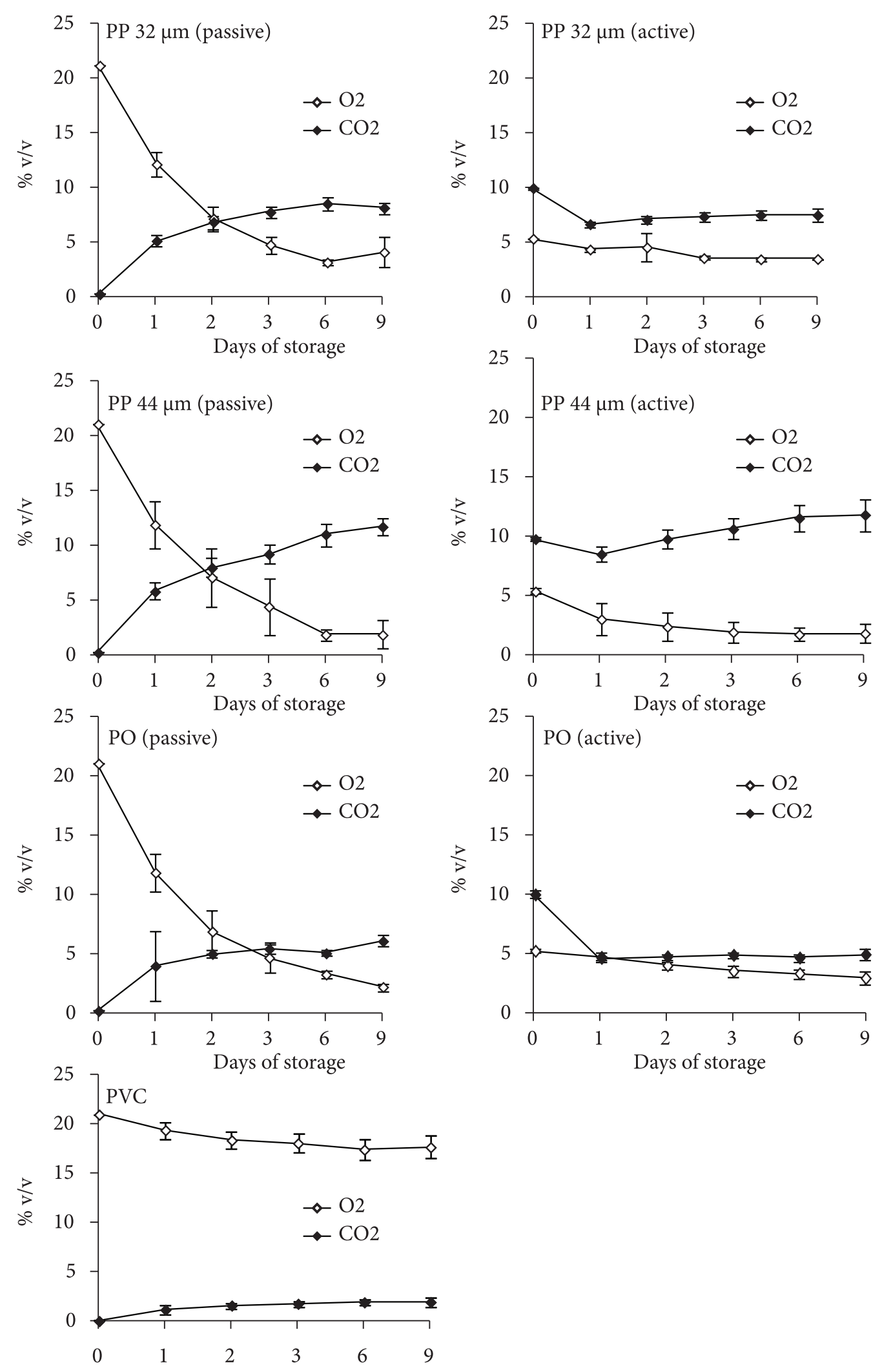

Days of storage

Figure 2. Gas composition (\%v/v) in packaging under passive or active atmosphere $\left(5 \% \mathrm{O}_{2}+10 \% \mathrm{CO}_{2}+85 \% \mathrm{~N}_{2}\right)$ containing minimally processed oranges stored at $12{ }^{\circ} \mathrm{C}$. Bars represent the standard deviation from the mean $(n=6)$. PP: polypropylene film; PO: polyolefin film Cryovac PD900; PVC: polystyrene trays covered with PVC stretch film. 
a substantial reduction in microbial contamination of melons under active modified atmosphere $\left(5 \% \mathrm{O}_{2}+20 \% \mathrm{CO}_{2}+75 \% \mathrm{~N}_{2}\right)$.

There was a reduction followed by an increase in $\mathrm{CO}_{2}$ levels when active modified atmosphere (injection of a $5 \% \mathrm{O}_{2}+10 \%$ $\mathrm{CO}_{2}$ gas mixture) was used. The initial reduction in $\mathrm{CO}_{2}$ levels is due to the predominant $\mathrm{CO}_{2}$ permeation from inside to outside the package in relation to its production by respiration. However, the $\mathrm{CO}_{2}$ production by respiration during storage was higher than permeation, favoring $\mathrm{CO}_{2}$ accumulation inside the package. There was a tendency for reduction of $\mathrm{O}_{2}$ concentration inside the PP packages throughout the storage period because the $\mathrm{O}_{2}$ consumption during the respiratory process is faster than the oxygen permeation from outside to inside the package. At first, there was a slight increase in the $\mathrm{O}_{2}$ levels inside the $\mathrm{PO}$ package, which results from a higher $\mathrm{O}_{2}$ permeability rate than respiration rate at $6{ }^{\circ} \mathrm{C}$. Such an increase was not observed for the PO package at $12^{\circ} \mathrm{C}$, probably due to the greater temperature effect on the respiratory activity than on the packaging permeability.

Among all packages evaluated at $6^{\circ} \mathrm{C}$, only the $\mathrm{PO}$ package under passive modified atmosphere resulted in an equilibrium atmosphere during storage. However, this equilibrium between gas permeability rate and respiration rate was only established on the ninth day of storage. When considering the packaging materials evaluated at $12^{\circ} \mathrm{C}$, only the PO package under passive modified atmosphere did not achieve gas equilibrium. The higher tendency for the packages at $12^{\circ} \mathrm{C}$ to achieve equilibrium is due to a higher compatibility between respiration and permeability rates at this temperature.

The equilibrium atmosphere reached at $12^{\circ} \mathrm{C}$ for PP $44 \mu \mathrm{m}$ package were $1.69 \% \mathrm{O}_{2}$ and $11.62 \% \mathrm{CO}_{2}$ under the active modified atmosphere system, and $1.75 \% \mathrm{O}_{2}$ and $11.28 \% \mathrm{CO}_{2}$ under the passive system. Although the $\mathrm{CO}_{2}$ level was very close to that of the injected gas mixture $\left(5 \% \mathrm{O}_{2}+10 \% \mathrm{CO}_{2}+85 \%\right.$ $\mathrm{N}_{2}$ ), the oxygen concentration was below $2 \%$.

Low oxygen contents were also found in this package at $6{ }^{\circ} \mathrm{C}$ on the ninth day of storage. Therefore, this packaging film shows very low oxygen permeability rate, which makes it unsuitable for the purposes of this study although the carbon dioxide permeability rate is adequate.

The equilibrium atmosphere for the PO package at $12{ }^{\circ} \mathrm{C}$ was $3.40 \% \mathrm{O}_{2}$ and $4.65 \% \mathrm{CO}_{2}$. The oxygen level in the $\mathrm{PO}$ package was similar to that of the injection level and also similar to what was observed for the PP $32 \mu \mathrm{m}$ film. However, the $\mathrm{CO}_{2}$ levels in the polypropylene $32 \mu \mathrm{m}$ film were closer to the injected levels.

The equilibrium atmosphere in the package headspace at $12{ }^{\circ} \mathrm{C}$ was achieved quickly under the active modified system. For the PP $32 \mu \mathrm{m}$ film the equilibrium atmosphere was achieved on the first day under the active modified atmosphere while on the sixth day under the passive modified atmosphere. The equilibrium atmosphere was achieved on the third day under the active modified system and on the sixth day under the passive modified atmosphere for the PP $44 \mu \mathrm{m}$ film, and on the third day of storage under the active modified system for the PO package.

\section{Conclusions}

The PP $32 \mu \mathrm{m}$ package led to gas levels close to the injected levels $\left(5 \% \mathrm{O}_{2}+10 \% \mathrm{CO}_{2}\right)$, for oranges stored at both $6{ }^{\circ} \mathrm{C}$ and at $12{ }^{\circ} \mathrm{C}$. Moreover, the visual aspect of this package is more attractive due to its transparency, shine, and stiffness.

Regarding the modified atmosphere system, the injection of the gas mixture anticipated the establishment of an equilibrium atmosphere in the PO package at $12{ }^{\circ} \mathrm{C}$. The gas leves at $6^{\circ} \mathrm{C}$ remained similar to the injected levels although it seems that the equilibrium atmosphere was not achieved.

\section{References}

AHVENAINEN, R. New approaches in improving the shelf-life of minimally processed fruit and vegetables. Trends in Food Science \& Technology, v. 7, n. 6, p. 179-187, 1996. PMid:21299575. http:// dx.doi.org/10.1016/0924-2244(96)10022-4

ARRUDA, M. C. et al. Hydrotermal treatment favors peeling of 'Pêra' sweet orange and does not alter quality. Scientia Agrícola, v. 65 , n. 2, p. 151-156, 2008. http://dx.doi.org/10.1590/S010390162008000200007

ARRUDA, M. C. et al. Conservação de melão rendilhado minimamente processado sob atmosfera modificada ativa. Ciência e Tecnologia de Alimentos, v. 24, n. 1, p. 53-58, 2004. http://dx.doi.org/10.1590/ S0101-20612004000100011

ARTÉS, F.; GÓMEZ, P. A.; ARTÉS-HERNÁNDEZ, F. Physical, Physical, physiological and microbial deteroration of minimally fresh processed fruits and vegetables. Food Science and Technology International, v. 13 , n. 3, p. 177-188, 2007. http://dx.doi. org/10.1177/1082013207079610

BARMORE, C. R. Packing technology for fresh and minimally processed fruits and vegetables. Journal of Food Quality, n. 10, p. 207-217, 1987. http://dx.doi.org/10.1111/j.1745-4557.1987. tb00859.x

CANTWELL, M. Postharvest handling systems: minimally processed fruits and vegetables. In: KADER, A. A. (Ed.). Postharvest technology of horticultural crops. 2nd ed. Davis: University of California, 1992. cap. 32, p. 277-281.

KADER, A. A. Biochemical and physiological basics for effects of controlled and modified atmospheres on fruits and vegetable. Food Technology, v. 40, n. 5, p. 99-104, 1986.

PANTÁSTICO, E. R. B. Postharvest physiology handling and utilization of tropical and subtropical fruits and vegetables. Westport: AVI Publishing Co., 1975. 560 p.

PRETEL, M. T. et al. The effect of modified atmosphere packaging on 'ready-to-eat'oranges. Lebensmittel.-Wissenschaft Und Technologie, v. 31, p. 322-328, 1998.

ROBERTSON, G. L. Modified atmosphere packaging. In: ROBERTSON, G. L. Food packaging: principles and practice. Boca Raton: CRC Press, 2006. cap.15. p. 313-330.

SARANTÓPOULOS, C. I. G. L. et al. Embalagens com atmosfera modificada. 2. ed. Campinas: CETEA, ITAL, 1996. 114 p. 